Vol. 20(2011): 42-61.

\title{
Examples of alien pathogens in Finnish potato production - their introduction, establishment and consequences
}

\author{
Asko O. Hannukkala \\ MTT Agrifood Research Finland, Plant Production Research, Fi-31600 Jokioinen \\ e-mail:asko.hannukkala@mtt.fi
}

\begin{abstract}
Most pathogens on potato have been imported into Finland via contaminated seed more than hundred years ago. The history of migration and the consequences for potato production of potato wart, blackleg and soft rot, Potato mop-top virus (PMTV) and its vector powdery scab are reviewed as examples of economically important and biologically different potato pathogens. Potato wart spread alarmingly during 1920-1960. Plant quarantine acts and the use of resistant cultivars were successful in eradicating the disease. The pathogens causing blackleg and soft rot increased rapidly in 1960-1970. Development of seed certification schemes after the end of the 1970s decreased disease incidence and made the disease insignificant other than for seed potato production. Introduction of new strains of blackleg bacteria in 2003 caused the disease again to become a considerable threat to potato production. PMTV was imported into Finland in the 1970s where it spread rapidly, especially in starch potato production. Currently it is common in all potato production except that of seed potato. The disease cannot be eradicated but contamination of clean fields can be prevented. New diseases can spread to Finland in future but population changes of existing pathogens have recently caused more problems than species completely new to Finland.
\end{abstract}

Key-words: alien invasive species, potato, potato wart, Synchytrium endobioticum, blackleg, soft rot, Pectobacterium, Dickeya, Potato mop-top virus, PMTV 
Vol. 20(2011): 42-61.

\section{Introduction}

Alien species can be introduced deliberately or unintentionally outside their natural habitats, usually through human activity. Species, or more often individual populations, are termed invasive if they are able to survive, reproduce and establish themselves in their new environment (Colautti and MacIsaac 2004). Moreover, new races and populations that displace existing ones can be treated as alien invasive populations (Luck et al. 2003). This is particularly typical of plant pathogens, which are capable of rapid genetic transformation that allows them to adapt to changing biotic and abiotic environments (Garrett et al. 2006).

Alien plant pathogens in agriculture have enormous economic impact. In the USA annual crop losses caused by agricultural diseases are estimated to be $\$ 21,000$ million and additional costs of disease control $\$ 500$ million (Pimentel et al. 2005). Certain pathogens also have marked effects on agricultural ecosystems, preventing or restricting cultivation of some crop plants in infected fields or over wider geographical regions, thus regulating dietary aspects of human society (Schumann 1991). Plant diseases, such as potato late blight (Phytophthora infestans (Mont.) De Bary), have also caused great famines, emigrations of human populations from one continent to another and serious political disturbances driven by hungry and angry underfed people (Zadoks 2008). In addition, millions of people have died or been seriously injured as consequences of food being poisoned by toxin-producing alien fungi and bacteria (Meggs 2009).

The introduction of several plant pests into Europe in the 19th century had disastrous consequences and called for the development of plant quarantine measures to prevent the spread and introduction of pests of plants and plant products (Schrader and Unger 2003). With the purpose of harmonising these measures, and of promoting measures for pest control, the International Plant Protection Convention (IPPC, https://www.ippc. int/) has developed to address organisms that are both directly and indirectly injurious to plants. It represents a framework for measures to combat invasive alien species, as far as they are plant pests, according to the Convention on Biological Diversity (http://www.cbd.int/).

Potato (Solanum tuberosum L.) is an ancient cultural crop that has been grown in the Andes for human consumption for more than thousand years. Spanish conquistadores imported the crop first to the Canary Islands and S. tuberosum subsp. andigena was probably grown there already in 1562 . At about 1600 potato was introduced as an exotic speciality for botanical gardens and royal palaces into the British Isles and various regions of continental Europe. In Europe it took 200 years before potato started to gain wide public acceptance as a cultivated food crop. At the end of the 1700s and beginning of the 1800 s emperors in different parts of Europe started to appreciate the nutritional value and potential productivity of potato for feeding a rapidly increasing poor population working for developing industrial companies. Wars and famines, official decrees and threats as well as stratagems spread potato cultivation throughout Europe. Introduction of $S$. tuberoum subsp. tuberosum from Chile around the 1850s was a huge step forward for developing European potato cultivation. Imported clones of this subspecies were adapted to long days and they were early enough to allow selection of varieties that were also productive in the climate of northern Europe (Olson 2001).

The first documents on potato cultivation in Finland date back to the 1720s when the landlord of the Fagervik estate imported some potato tubers from Sweden to see if the crop could be grown in the Finnish conditions. During 1730-1760 potato use and cultivation spread very slowly, mainly among the higher social classes in southern and western Finland. Finnish soldiers returning from continental European wars in the 1760s had a major impact on increasing potato growing among ordinary peasants. In 1797 the Finnish Economics Society was founded and got substantial funding from Swedish, and later Russian, governors to provide free seed potato for farmers until the 1830s. In the second half of the 1800 s potato had largely displaced turnip (white turnip) Brassica rapa var. rapa L. and swede (yellow turnip) Brassica napus 
Hannukkala, A. Alien potato pathogens

var. napobrassica L. in the Finnish diet and in the 1900s it became one of the basic foodstuffs along with cereals (Varis and Pietilä 2001). During recent decades potato cultivation in Finland has become more and more specialised and professional, and the growing area has stabilised at around 28,000 hectares. Production is highly concentrated in an approximately $100 \mathrm{~km}$ wide zone along the Gulf of Bothnia (Fig. 1), between latitudes $60^{\circ}$ and $63^{\circ}$ $\mathrm{N}$ and longitudes $22^{\circ}$ and $25^{\circ} \mathrm{E}$, which increases pest risks (Hannukkala et al. 2007).

Most potato diseases have been imported to Finland in infected potato tubers at the end of the 1800 s or the beginning of the1900s (Table 1). The aim of this review is to describe migration of four economically important, taxonomically and biologically dissimilar potato diseases into and within

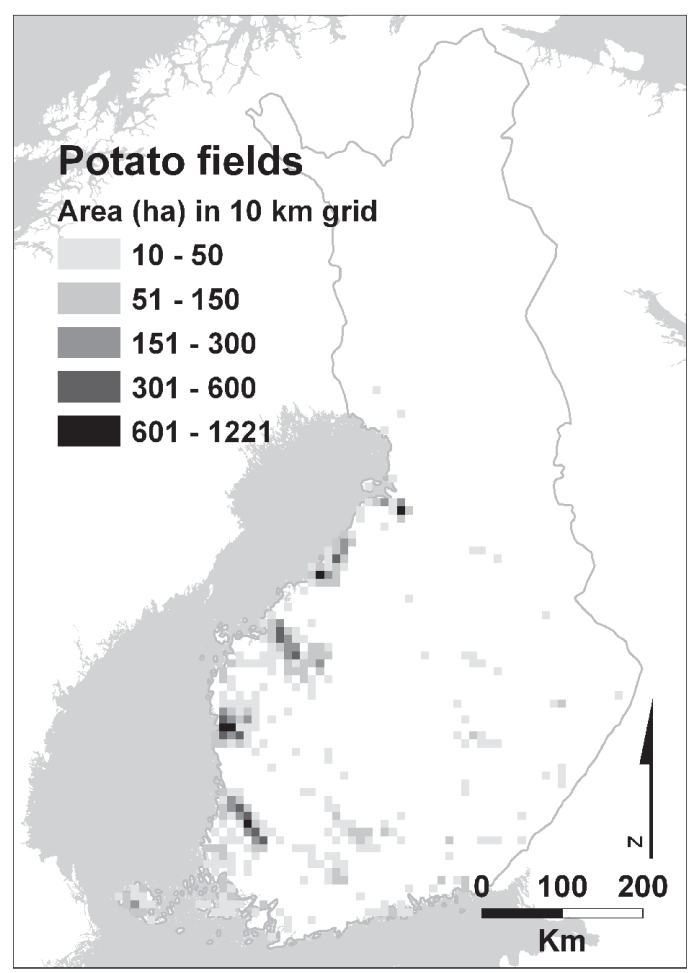

Fig. 1. Geographic distribution of potato fields and their area in ten kilometre grids in Finland in 2007. The production area has not changed markedly and the map corresponds well with the distribution in 2010.
Finland, their historical and current distributions, significance, management and recent biological changes in pathogen populations. Future perspectives in changing production environment for each disease are discussed. These diseases were selected because they currently are or have been very problematic for potato production and their occurrence in Finland has been relatively well documented. Migration and consequences of potato late blight probably the most devastating potato disease in Finland will be reported in a separate paper (Hannukkala, unpublished). Especially prior to the 1990s tradition of Finnish agricultural research was not to publish extensively in the international scientific journals. Many scientifically qualified surveys were only published in various research reports in Finnish and sometimes in different congress proceedings in English or in German. One prospect of this review is to highlight the results of these valuable studies first time for a wider audience.

\section{Potato wart - disease almost eradicated from Finland}

Potato wart pathogen [Synchytrium endobioticum (Schilbersky) Percival] is an example of a persistent soil-borne pathogen that after its introduction was rapidly dispersed throughout southern Finland between the 1920s and 1960s in allotment gardens by peasants and industrial workers moving from one place of employment to another. Development of wart immune potato cultivars, and implementing adequate quarantine actions, enabled almost complete eradication of the disease until the 2000s. This eradication process took more than 40 years and the potential spread of numerous novel pathotypes recently found in Central Europe could rapidly nullify the success story of eradication if quarantine measures are relaxed in the absence of the disease.

S. endobioticum is a pathogen that belongs to the kingdom Fungi where it is placed in phylum Chytridiomycota and class Chytridiomycetes (Hib- 
Vol. 20(2011): 42-61.

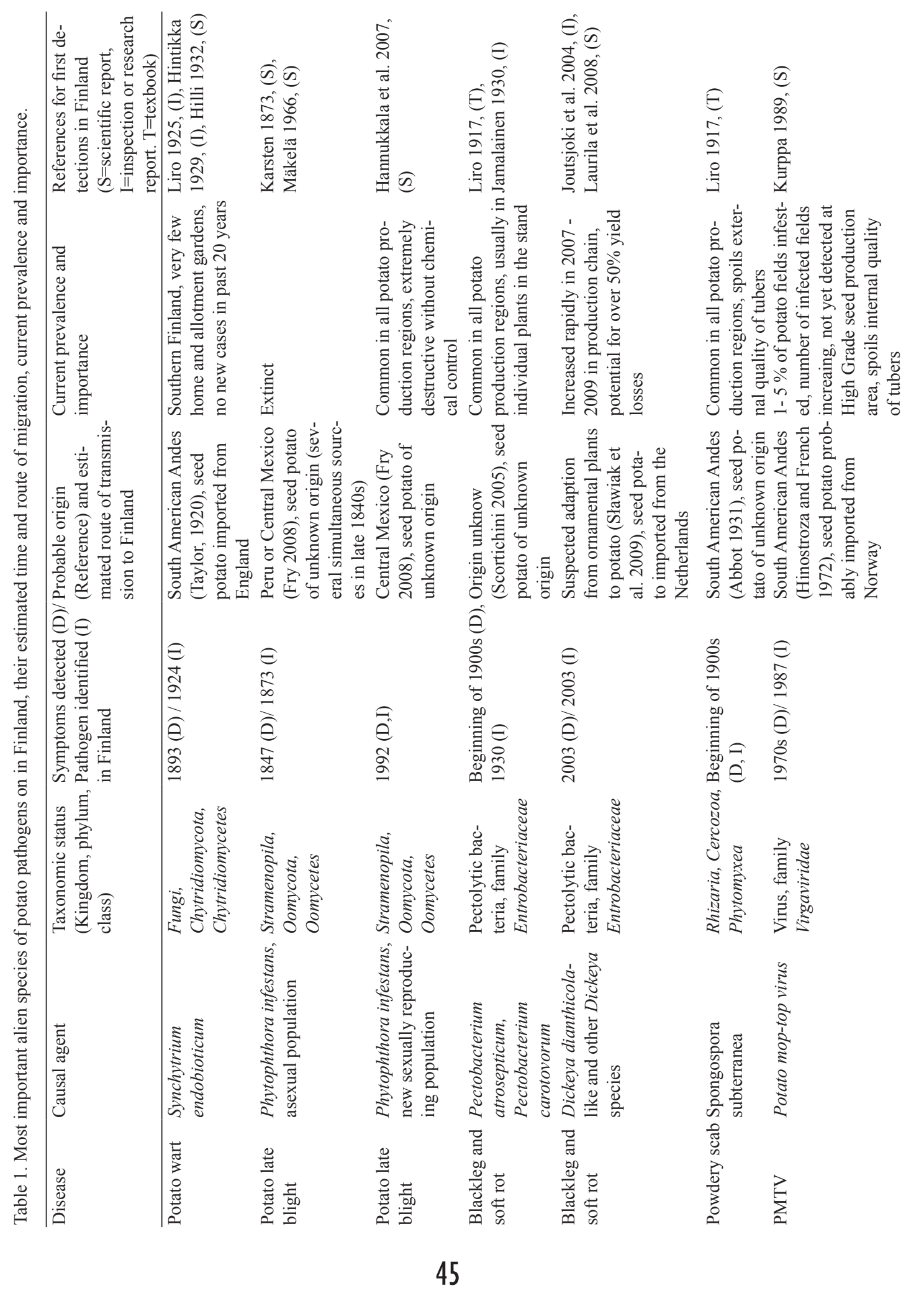


Hannukkala, A. Alien potato pathogens

bet et al. 2007). The fungus is an obligatory parasite characterised by a vegetative phase as a singlecelled thallus inside host cells, asexual reproduction as single flagellate zoospores and survival as thick walled resting spores (Alexopoulos et al. 1996). The pathogen stimulates its host to produce hypertrophic outgrowths, warts, on tubers, stolons and stem bases (Fig. 2a) (Percival 1910). The fungus does not attack potato roots. Individual tubers can be entirely transformed into warts unsuitable for human consumption or the processing industry (Hampson and Coombes 1985). Often wart symptoms on tubers can remain rather weak resembling those of common scab or powdery scab (Fig. 2b).

$S$. endobioticum is a specialised pathogen of solanaceous plants. In Finland the only relatively widespread alternative host is tomato, Solanum lycopersicum L. The pathogen can infect weeds such as Solanum nigrum L. and Solanum dulcamara L. (Martin 1929) among other solanaceous species (Hampson 1979). The role of alternative hosts in maintaining wart disease in Europe is regarded as more or less academic interest (Baayen et al. 2006).

\section{Introduction of potato wart into Europe and Finland}

The disease was transmitted from the Andes to Europe at the end of $19^{\text {th }}$ century. The first symptomatic tubers were found in 1876 in England (Taylor 1920). The causal agent of potato wart disease was first described as Chrysophlyctis endobiotica by Schilberdksky (1896) and Percival (1910) changed the name to Synchytrium endobioticum. The disease spread gradually during the following decades and hundreds of thousands of outbreaks occurred all over Europe, especially during the 1920s (Hampson 1993).

In Finland the disease was officially initially detected at Kirkkonummi ( $60^{\circ} 08^{\prime}$ N, $\left.24^{\circ} 29^{\prime} \mathrm{E}\right)$ in 1924 by Liro (1925), who assumed that potato wart arrived in the potatoes brought as provision by Estonian spirit smugglers. A poor local farmer's wife used the remains of the potato for seed, introducing the pathogen into her garden. More than 100 other wart disease outbreaks were reported in 1924-1928 in southern Finland and various assumptions on the
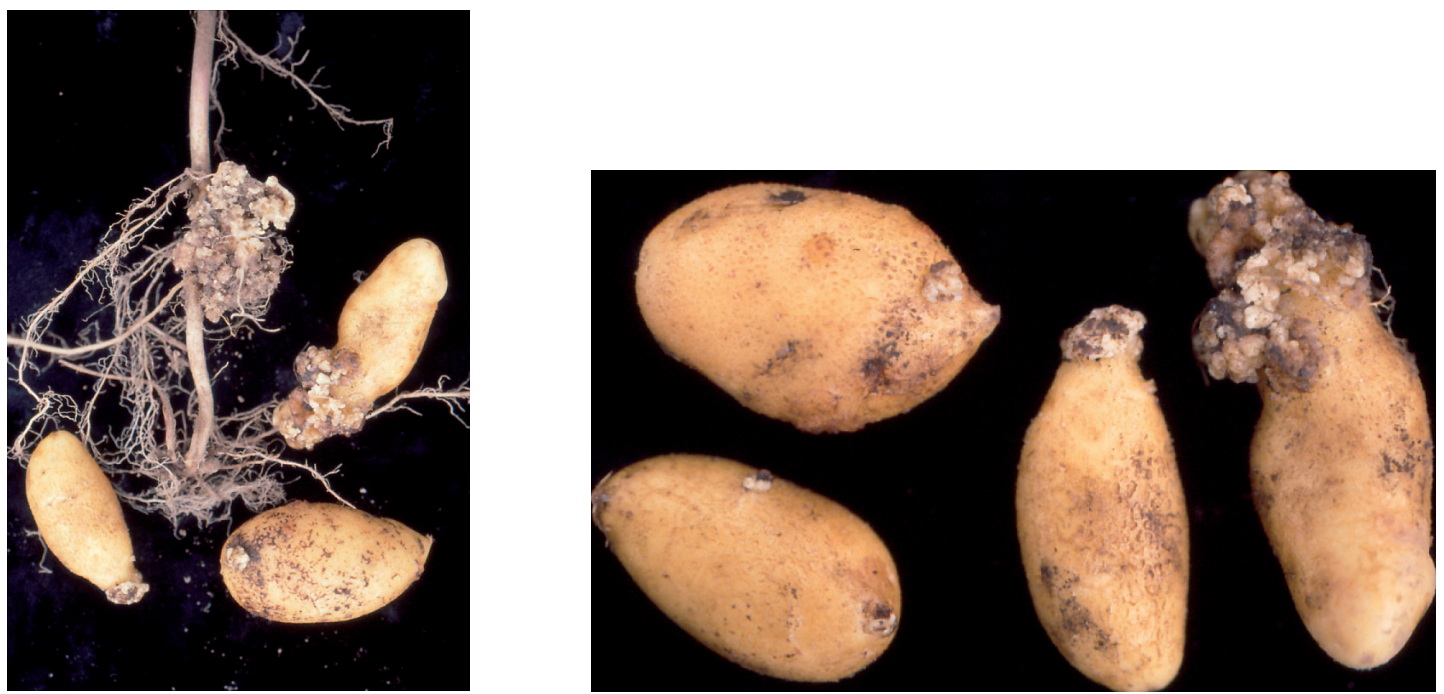

Fig. 2a. The fungus Synchytrium endobioticum causes potato wart, hypertrophic outgrowths on tubers and stem bases of potato. 2 b. In tubers weak symptoms sometimes resemble those caused by powdery or common scab. 
Vol. 20(2011): 42-61.

origin of the disease were made (Hintikka 1929). Extensive studies by Hilli (1932) revealed that the disease actually had been imported into Finland at Arima's estate at Pusula $\left(60^{\circ} 24^{\prime} \mathrm{N}, 23^{\circ} 31^{\prime}\right.$ E) already in 1893. In spring 1893 the previous owner of the farm had imported seed potato cv. 'Magnum Bonum' from England. Following seasons the former foreman of the farm, J. Ekberg, had detected obviously wart symptomatic potatoes at several separate sites in the farm. According to bookkeeping records of the farm, no potato had been introduced into the farm during the preceding decades and the subsequently introduced potato lot was purchased by the farm in 1903 .

Further investigations of Hilli (1932) revealed that almost all outbreaks detected in 1924-1928 could be traced back to the estate Arima. Workers on the estate moving out with their families to other sites in southern Finland took seed potato and wart with them. They often distributed their seed potato as a gift for their new neighbourhoods providing rapid spread of the disease at the new site. Furthermore, industrial workers growing potato in allotment gardens efficiently dispersed the disease by exchanging propagation material. One wart outbreak in Nauvo $\left(60^{\circ} 10^{\prime} \mathrm{N}, 21^{\circ} 50^{\prime} \mathrm{E}\right)$ in 1929 , in a distant archipelago, was demonstrated to originate from seed potato imported from the Neth-

erlands. Two outbreaks at Lappee (currently part of Lappeenranta $60^{\circ} 59^{\prime} \mathrm{N} 28^{\circ} 19^{\prime} \mathrm{E}$ ) and Joutseno $\left(61^{\circ} 09^{\prime} \mathrm{N}, 28^{\circ} 36^{\prime} \mathrm{E}\right)$ in south-eastern Finland far away from Arima's estate at Pusula above were suspected to originate from potato imported from Germany.

During 1924-1931 a total of 209 infested fields were detected in Finland and in 1932 -1943 the number of diseased fields increased by 199. During 1944-1954 there were 5 to 26 new wart cases annually and in 1954 the total number of infected fields was 582 (Ylimäki 1955). Until 1990 wart was found on approximately 850 fields in Finland, after which no new cases were reported (Fig. 3). From 1924 to 1954 there were 366 infested fields in urban centres, while 216 infested fields were found in rural areas. The average size of infested fields in urban centres was 0.006 ha and in rural areas 0.01 ha. By the end of 1954 the disease occurred in south and southeastern Finland. The northernmost observation was at Lieksa (63 $\left.19^{\prime} \mathrm{N}, 30^{\circ} 13^{\prime} \mathrm{E}\right)$ (Ylimäki 1955).

Number of new wart cases per year (bars)

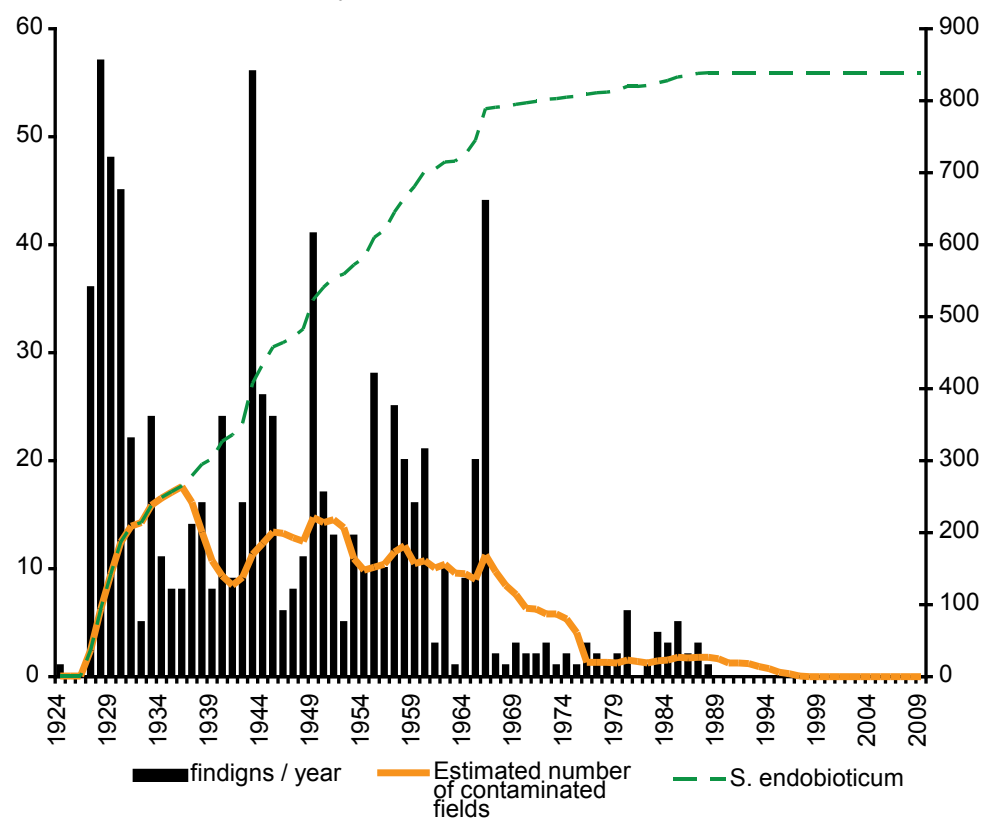

Fig. 3. Occurrence of potato wart infected fields in Finland from the 1920 s to the present. Estimated number of fields is calculated based on assumption that the field is free from contamination during 10 years of quarantine after original report. The graph for 19241954 is constructed from data published by Ylimäki (1955), 1955-1980 annual reports of disease occurrence in Finland published by plant protection experts (not listed in references) and 1981-2008 from personal communication with Mirkka Soukainen. 
Hannukkala, A. Alien potato pathogens

\section{Consequences of wart for potato production}

Potato wart is a potentially devastating disease for potato production. In severely infested fields crop losses can range from $50 \%$ to $100 \%$ (Hampson 1993). In Finland yield losses in the range of 20-30\% have been reported (Hilli 1932). It is a widespread though sparsely distributed disease in Europe. It is also found at restricted locations in America, Asia, South Africa and New Zealand (CAB International 1983).

The pathogen is easily transmitted by any human activities where seed potato or infected soil is moved between sites (Baayen et al. 2006). Characteristically throughout its history the disease has not been a significant problem for rural potato production, while home and allotment gardens have suffered from the disease in industrial (Hilli 1932, Moore 1957) and mining districts (Sanders 1919). After its introduction into a field the disease is extremely difficult to eradicate because the fungus produces resting spores able to survive in the soil without susceptible hosts for 10-30 years (Curtis 1921, Schaffnit and Meyer-Hermann 1930, Pratt 1976). The appearance of wart in potato production leads to severe limitations for potato cultivation and expensive eradicative efforts for the farmer. Fortunately during the last three decades wart has only been found in home and allotment gardens in Finland. In the 1990s and 2000s no new cases were reported to the Finnish Food Safety Authority (EVIRA) and all previously identified sites have proven to be free of the disease after 10 years of quarantine (Mirkka Soukainen, personal communication).

\section{Potato wart management}

Due to its destructive and persistent nature, eradication, suppression of spread within and between countries by legislation, cultural practices and breeding resistant cultivars have proved to be the most effective tools in disease management. Chemi- cal control of the soil-borne pathogen has never been adequate (Hampson 1981) and environmental hazards connected with soil fumigation practically rule out chemical wart control in current potato production (Baayen et al. 2006).

\section{Legislation to eradicate the disease}

The rapid dispersal of wart disease in the early 1900s in Europe necessitated development of legislation to limit the spread of the pathogen between and within countries. The first law for plant protection in Finland was passed on 1925. According to the legislation all imported potato lots had to be inspected and proved to be free of wart disease, among other diseases listed. Currently the pathogen is classified as an IAII quarantine pest (pest already present in the EU; entry or spread within the EU is prohibited) in EU Directive 2000/29/EC (European Union, 2000) and Finnish legislation is harmonized with the EU Directive.

The current regulations in Finland forbid potato production on infested fields. In neighbouring fields only wart-resistant cultivars can be grown. The field where wart is found is deemed infested for 10 years, after which soil samples are investigated by EVIRA. If wart is still present the field is regarded as being infested for a further 10 years.

\section{Germplasm resistance}

Already during first years of the 1900s extensive variety testing was initiated in Europe, including Finland, to find wart resistance (Taylor 1920, Hilli 1932). Fortunately, complete immunity to certain races of wart pathogen was relatively easy to find in breeding material. Nonetheless first indications of the breakdown of the race specific resistance were observed already during the 1920s (Glynne 1926). Until the early 1940 s resistance against wart was regarded as being very durable because only one pathotype of the fungus, 1(D1) was recognized (Köhler 1931). In 1941 wart development in formerly resistant cultivars caused by new pathotypes was discovered (Braun 1942). As additional and more aggressive pathotypes were found (Hey 1957, Moore 1957), the work on testing of cultivars was accelerated and material once thought to be resistant had to be retested (Thiede and Wierling 1960). 
Vol. 20(2011): 42-61.

The success of phytosanitary methods against wart disease in Europe has been largely due to the discovery in the early 1900 s of resistant potato cultivars and subsequent breeding programmes for resistance (Langerfelt et al. 1994, Stachewicz 1996). However, up to 2006 at least 37 different pathotypes were reported, 18 of them being potentially dangerous, 7 extinct and the rest of minor importance. Very few current potato cultivars are resistant to more than one pathotype. The current status of pathotype classification is confusing because four different nomenclature systems are used. Most of the important pathotypes are found in Germany, the Czech Republic and Ukraine (Baayen et al. 2006).

\section{Current status and future perspectives}

The occurrence of potato wart in Finland is currently well monitored. In recent years no new cases have been reported, but the disease is present in certain home and allotment gardens and tight quarantine regulations need to be followed in the future. In Finland there are no reports of breakdown of wart resistance of currently grown cultivars. The pathotypes of the fungus in Finland have never been investigated, but the consistent cultivar resistance indicates that the Finnish S. endobioticum population represents the old 1(D1) population.

Limited resistance in current cultivars against pathotypes other than 1 (D1) makes potato production still very vulnerable to wart disease. If new pathotypes start to spread suddenly there are limited means available for disease management. Therefore, it is extremely important to maintain high standards in quarantine inspections, especially when potato is imported from countries where new pathotypes exist. It is also essential for potato breeders to seek new sources of resistance against new pathotypes. According to Baayen et al. (2006), it is almost impossible to accumulate resistance against several wart pathotypes in one potato cultivar. Potato wart pathogen is adapted to a range of environments and predicted climate change probably does not have much effect on disease risk during next few decades.

\section{Blackleg and soft rot serves as an example of a disease com- plex caused by old and new bacteria}

Blackleg and soft rot serves an example of a disease that has been relatively stable in Finland from the end of the 1800s to the 1980s. Improvements in seed production, cultivation and storage technologies in the 1980s and thereafter reduced the importance of the disease and rendered it mainly a seed quality problem. Import and rapid establishment of new aggressive strains in the 2000s made blackleg and soft rot an increasingly serious problem in all potato production (Pietarinen and Seppänen 1981, Harju and Kankila 1993, Hannukkala and Segerstedt 2004).

Blackleg and bacterial soft rot on potato is caused by a group of pectolytic bacteria belonging to the family Enterobacteriaceae, formerly classified into genus Erwinia (De Boer 2003). The genus Erwinia was described in 1917 to include all Enterobacteriaceae causing plant diseases, irrespective of their relatedness to other members of the family. Over the years this has caused many taxonomic difficulties, and led to a thorough revision of phylogenetic relationships and nomenclature of Erwinia spp. in the 2000s (Toth et al. 2003). Gardan et al. (2003) suggested grouping these bacteria into the genus Pectobacterium due to their unique pectolytic activity, sequence analysis of the 16S ribosomal DNA and DNA hybridization studies. Samson et al. (2005) proposed the currently accepted nomenclature. Blackleg and soft rot bacteria include: Pectobacterium atrosepticum (former Erwinia carotovora subsp. atroseptica), Pectobacterium carotovorum subsp. carotovorum (former Erwinia carotovora subsp. carotovora) and several species of Dickeya (formerly Erwinia 


\section{AGRICULTURAL AND FOOD SCIENCE}

Hannukkala, A. Alien potato pathogens

chrysanthemi). Traditionally all of the species have been regarded as causal agents of soft rot in tubers, while blackleg was thought to be caused by P. atrosepticum in temperate regions and Dickeya spp. in subtropical and tropical regions of the world (Toth et al. 2003). The host range of $P$. atrosepticum is restricted to solanaceous plants while the other species can cause diseases on members of numerous different plant families (Pérombelon and Kelman 1980, Pérombelon 2002, De Boer 2003).

Infection by these bacteria usually results in maceration and rotting of parenchymatous tissue of the affected organ, but on the growing plant initial symptoms can be diverse. Early decay of the seed potato before emergence or death of sprouts at or soon after emergence is a common manifestation of the disease. The basal stem typically turns slimy and dark brown or black (Fig. 4a) emanating a strong, unpleasant odour. In storage complete rotting of tubers, initially in small pockets, often proceeds rapidly, resulting in massive decay of tubers (Pérombelon and Kelman 1980, Ma et al. 2007).

\section{Blackleg and soft rot in Europe and Finland}

The disease has been known in Europe and North America since the end of the 1800s. Frank (1899) in Germany was probably the first author to connect both blackleg symptoms, "Schwarzbeinigkeit", and tuber wet rot symptoms to a bacterial parasite. In the beginning of the 1900 s there were several names suggested for the bacteria, including Bacillus atrosepticus and Bacillus phytophthorus (Morse 1917). The geographical centre of origin or routes of migration of blackleg and soft rot bacteria into different parts of the world is not possible to establish with certainty. This is due to wide host range (except for $P$. atrosecticum), rapid and unpredictable genetic evolution of the bacteria and the fact that disease can remain latent for years after its introduction to a region before environmental conditions favour a disease outbreak (Scortichini 2005).

The occurrence of blackleg and soft rot in Finland before the 1980s is, scientifically, poorly documented. Liro, in his textbook from1917, states that blackleg and soft rot caused by different bacteria were common in potato fields in the beginning of the 1900s, but usually damaging only individual plants in the stand. Jamalainen (1930), who also studied bacteria associated with rot by microscope, named the causal agent Bacillus phytophthorus. According to him the disease was common in small plots where potato was grown year after year. It was common that up to $10 \%$ of plants had symptoms. Pohjakallio (1963) estimated blackleg and soft rot caused by Erwinia species to be a common, but usually not a very severe disease in potato fields. In
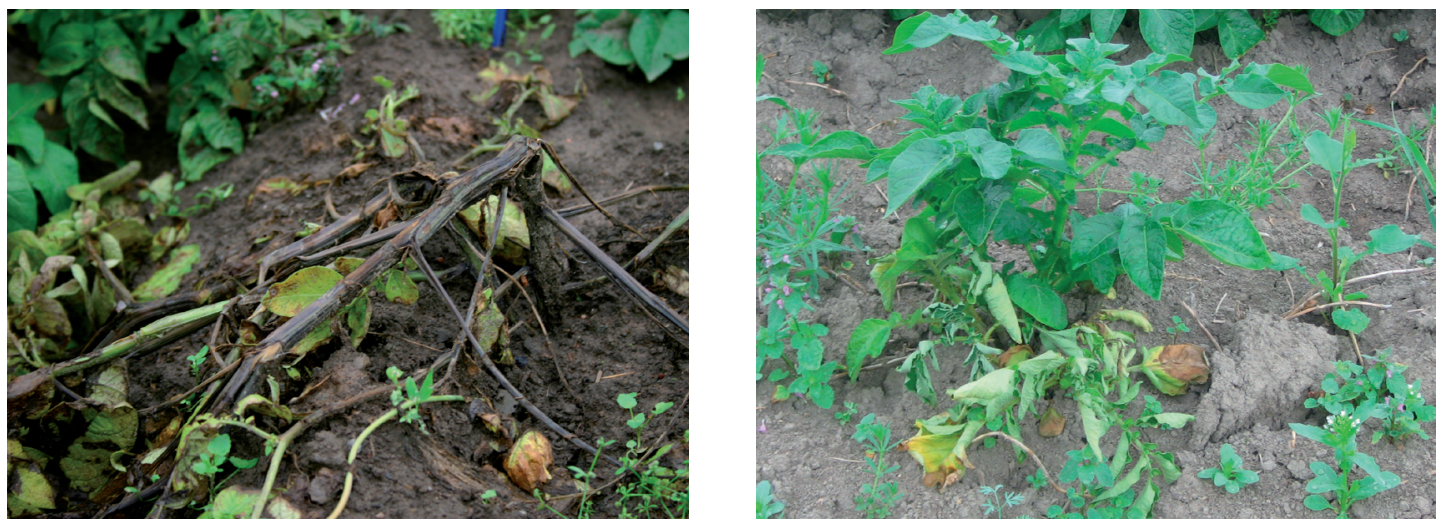

Fig. 4a. Typical blackleg symptoms caused by Pectobacterium and Dickeya species. 4b. Wilt caused by new Dickeya strains. 
Vol. 20(2011): 42-61.

1963-1967 the incidence of blackleg ranged from 6 to $36 \%$ and soft rot from 10 to $30 \%$ in potato samples collected from various sources (Puttonen 1968). The disease is said to have increased alarmingly at the end of the 1960s and beginning of the 1970s (Seppänen 1972). Blackleg incidence markedly decreased after 1976 (Harju and Kankila 1993), when production of healthy seed potatoes using meristem culture methods was established (Pietarinen and Seppänen 1981).

The first survey in Finland that included feasible serological detection of bacteria was carried out in seed potato production in 1981-1983 by Harju and Kankila (1993). In their study an average 30\% of seed tubers were infected and P. atrosepticum was present in $67 \%$ of the infected tubers. P. carotovorum subsp. carotovorum was occasionally isolated from blacklegged stems in southern Finland, but in all cases $P$. atrosepticum was also present in diseased tissue. In this study none of bacterial strains belonged to the Dickeya (E. chrysanthemi) group. In spite of a rather high level of infection in seed, low frequencies of blackleg were detected in the field, which seems to be typical for $P$. atrosepticum (De Boer 2003, Pérombelon 2002).

After the 1981-1983 survey Finnish seed potato production was developed with an emphasis on blackleg control (Harju and Kankila 1993). A corresponding survey during the early phases of seed production chain was carried out in 20012003 (Hannukkala and Segerstedt 2004). The level of latent Pectobacterium infection was markedly decreased in comparison with a previous survey. In the $4^{\text {th }}$ seed generation an average of $2.8 \%$ (range $0-8.2 \%$ ) of tubers were infected (Hannukkala et al. 2004a, 2004b) while the corresponding figures in the survey of Harju and Kankila (1993) were 22\% (range 0-57\%). P. atrosepticum and P. carotovorum subsp. carotovorum were equally common in infected tubers (Hannukkala et al. 2004a, 2004b). Improved seed quality was also reflected in ware potato production and in a survey carried out in 1997-2003 typically blackleg symptoms were detected on less than $2 \%$ of plants in crops inspected. Furthermore, the occurrence of tubers with visible soft rot was normally less than $2 \%$ (Rahkonen et al. 2004).

\section{Population changes in blackleg and soft rot causing bacteria and disease aetiol- ogy in the 2000 s}

During the latter half of the 2000s the concept of blackleg and soft rot in Europe rapidly changed. Dickeya species (Erwinia chrysanthemi), which were formerly regarded as potato pathogens of tropical and subtropical regions, started to spread in Europe (Palacio-Bielsa et al. 2006, Laurila et al. 2008, Czajkowski et al. 2009). The occasional findings of E. chrysanthemi in northern Europe had been reported already during the 1990s, but not in potato production (Janse and Ruissen 1988, Persson 1991).

Dickeya spp. were first isolated in Finland from a diseased potato stem base showing typical blackleg symptoms in 2003 in Tyrnävä $\left(64^{\circ}\right.$ $\left.47^{\prime} \mathrm{N}, 25^{\circ} 49^{\prime} \mathrm{E}\right)$. The seed potato in the field had been imported from the Netherlands and the isolate was identified as E. chrysanthemi using metabolic tests and specific PCR primers (Joutsjoki et al. 2004). During the following years different stem rot symptoms from potato fields in different parts of Finland were noted and samples collected, including water samples from rivers in southern and western Finland, to isolate and characterize Pectobacterium and Dickeya strains. In 2003-2004 P. atrosepticum was present in $42 \%$ of the stem samples. $P$. carotovorum was found in $27 \%$ and Dickeya spp. in $23 \%$ of the samples (Joutsjoki et al. 2005). Further studies of Laurila et al. (2008) showed that $P$. carotovorum and Dickeya spp. are relatively common also in river waters in different parts of Finland. They also showed that on the basis of 16S-23S and 16S rDNA sequences, the Finnish Dickeya strains fell in three phylogenetic groups. One of the groups resembled closely $D$. dianthico$l a$, a quarantine pathogen of many horticultural crops. The sequences of the two other groups did not match with any published Dickeya sequences and they were termed group I and group III.

Finnish $D$. dianthicola-like strains are very aggressive on potato, causing typical blackleg symptoms and reducing yield by up to $50 \%$. Strains in group I caused severe symptoms on potato, includ- 
Hannukkala, A. Alien potato pathogens

ing blackleg (Fig. 4a), but also wilting (Fig. 4b) and other atypical symptoms for blackleg disease. Strains in group III proved to be weak pathogens of potato (Laurila et al. 2010). Certain highly aggressive Dickeya strains, in comparison with $P$. atrosepticum, were also reviewed by Palacio-Bielsa et al. (2006). Finnish Dickeya group I seems to be almost identical to a new clade within the Dickeya genus, tentatively called D."solani", recently described from findings in Dutch potato fields (Sławiak et al. 2009, Laurila et al. 2010).

\section{Blackleg and soft rot management}

Traditionally blackleg has been regarded as a seedborne disease and the main emphasis in disease management has been on production of 'clean' seed. Seed certification schemes are based on roguing and field inspections. These schemes do not reveal latent infections even though they are the most important source of inoculum in the production chain. The problem in seed production is that bacteria-free basic seed will become contaminated during propagation in an open field. Much effort in seed production has been spent reducing the number of generations of multiplication in the open field before the seed is sold to the end user (Pérombelon 1992). In Finland, the first blackleg symptoms are typically detected during the third seed generation in the open field (Harju and Kankila 1993).

To reduce contamination of the highest seed classes, mechanical haulm destruction prior to harvest should be avoided because it generates aerosols containing blackleg bacteria, which can infect nearby crops. Dry storage conditions are paramount to prevent a rise in tuber contamination because bacteria can multiply rapidly in moist conditions. Great care should be taken to avoid wounding during mechanical handling, especially during grading (Pérombelon 1992). A very critical phase in seed production is how seed is handled and stored between grading and planting. If seed is stored under warm conditions, in large containers, tubers will be easily exposed to low-oxygen conditions, which can launch extremely rapid multiplica- tion of bacteria in lenticels of the tubers (Toth et al. 2003).

To date blackleg and soft rot management is solely based on healthy seed. The end user of the seed has very limited possibilities for disease control. There are no chemical compounds effective against blackleg bacteria and the level of disease can only be seen after the crop has been planted in the field (Pérombelon 1992).

\section{Current status and future perspectives}

The bacterial population causing blackleg and soft rot changed rapidly during the second half of the 2000s in Finland and some of the new Dickeya strains are definitely more destructive than $P$. atrosepticum (Laurila et al. 2010). The current distribution of different bacteria causing blackleg in Finnish potato fields is not known. According to analyses of MTT's seed potato laboratory, Dickeya strains in 2006-2009 infected 30-40\% of seed samples studied (Hannukkala et al. 2009). There are indications that Dickeya strains are often connected to fields with very severe blackleg epidemics. In the case of $P$. atrosepticum, only individual plants are usually diseased (Yeshitila Degefu, personal communication). In the Netherlands crop losses due to new Dickeya strains have increased 5 fold from $€ 5$ milj to $€ 25$ milj from 2002 to 2007 (van der Wolf et al. 2010).

For seed certification inspections, which are based on visible symptoms in the field, a variety of new symptoms can be problematic (Laurila et al. 2010). Inspectors do not necessarily recognize the symptoms as blackleg and there is the risk that rather heavily infested fields will be certified for seed potato. Therefore, accurate ELISA or PCRbased tests should be applied during seed health inspections.

Traditionally blackleg management has been based on keeping the disease level low enough in seed potato (De Boer 2003, Pérombelon 2002). New Dickeya strains have wide host ranges and they are frequent also in river waters that can be used for irrigation (Pérombelon and Kelman 1980, 
Vol. 20(2011): 42-61.

Pérombelon 2002, Laurila et al. 2008, 2010). Moreover Dickeya strains can probably survive in soils much longer than Pectobacterium spp., but there are no data on their longevity during Finnish conditions. All this means that there can be several infection sources within and around potato fields and healthy seed is no longer sufficient for disease management.

Rapid changes in bacterial species causing blackleg and soft rot emphasizes the importance of continuous follow-up of possible changes in bacterial populations in potato fields. The bacterial genome is flexible and minor genetic changes can produce new strains adapted to totally different environments than their parents. For example, the new clade of Dickeya currently found on potatoes in Finland, The Netherlands and Israel is suspected to have evolved from strains previously attacking bulbs of ornamental plants in temperate climates (Sławiak et al. 2009, Tsror 2009, Laurila et al. 2010). Dickeya solani has been suggested as the name of the new clade, but further taxonomic studies are needed to establish Dickeya nomenclature. The Dickeya complex is also a very good example of how fast current international trade in seed potato can distribute diseases not regarded as quarantine pests. The predicted climate change favours bacterial diseases that thrive in warm and moist environments and the risk for migrations of bacterial diseases, like brown ring rot (Ralstonia solanacearum), not yet in Finland, increases.

\section{Potato mop-top virus and its vector Spongospora subterranea}

Potato mop-top virus (PMTV) is an example of a relatively recently introduced new potato pathogen of very persistent nature. It is fully dependent on its vector, Spongospora subterranea, which has been present in Finland since at least the beginning of the 1900s. Widespread occurrence of the vector, ignoring the presence of the disease for several years after its import and lack of true genetic resistance against the disease in potato germplasm, have probably enabled rapid spread of the virus throughout Finland.

PMTV causes mop-top disease of potato and is placed into a new virus family, Virgaviridae, being a representative of the genus Pomovirus (Adams et al. 2009). PMTV seriously spoils internal quality of potato tubers (Jones and Harrison 1969) by causing brown necrotic arcs, termed spraing, (Fig. 5a) and other types of internal necrotic flecks (Harrison and Jones 1971). The symptomatic tubers are unusable as ware potatoes or in the food processing industry (Nielsen and Mølgaard 1997). Foliar symptoms in plants grown from infected tubers can include pale yellow or yellow blotches, rings and chevrons on the lowest leaves. Severe secondary infection leads to shortening of the internodes, resulting in a dwarfed appearance termed mop-top (Calvert
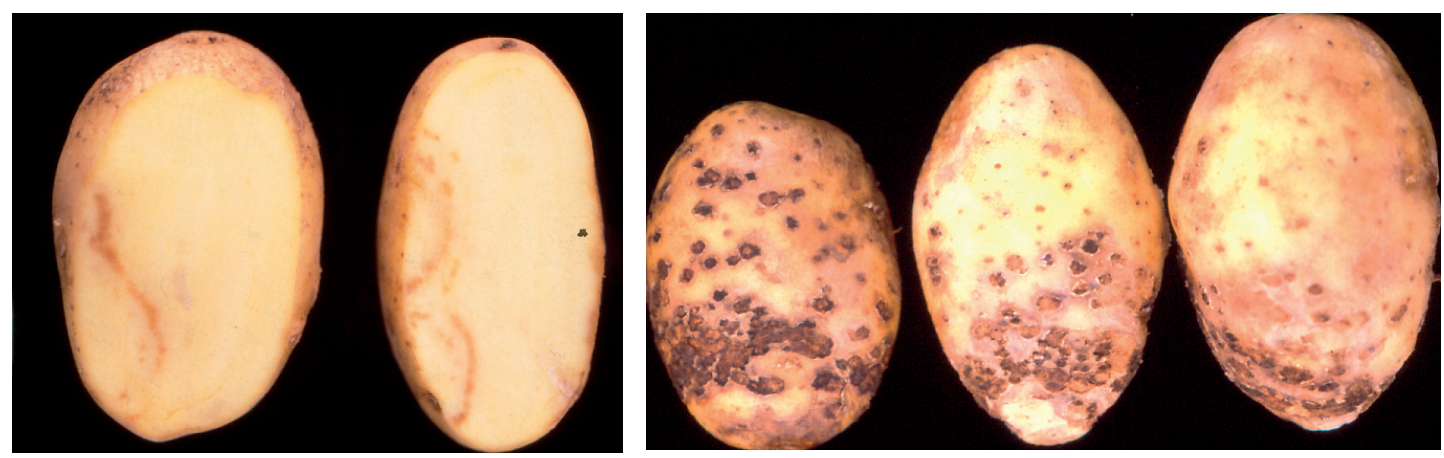

Fig. 5a. Potato tubers with spraing symptoms caused by PMTV. 5b. Powdery scab caused by Spongospora subterranea. 
Hannukkala, A. Alien potato pathogens

and Harrison 1966, Kurppa 1989a, 1989b). The appearance of foliar symptoms needs specific environmental conditions and foliar symptoms are extremely rare in open fields in cultivars grown in Nordic countries other than Norway (Santala et al. 2010). In Scotland foliar symptoms are very common and $19-41 \%$ of infected tubers, depending on cultivar, have produced foliar symptoms (Carnegie et al. 2010)

PMTV cannot infect potato in the absence of its only known vector, Spongospora subterranea (Wallr.) Lagerh. (Jones and Harrison 1969, Kirk 2008), which causes powdery scab on potato (Fig. $5 b)$. The pathogen is currently placed into a recently established supergroup of organisms, Rhizaria. It is a representative of the kingdom Cercozoa, belonging to Phylum Phytomyxea and class Plasmodiophorida (Bass and Cavalier-Smith 2009). It is closely related to Plasmodiophora brassicae Woronin, the causal agent of club root of cruciferous plants (Karling 1968). Powdery scab is often classified as a tuber skin blemishing disease, causing different types of 'cosmetic' scab and tumour symptoms resembling those of common scab and wart on potato tubers (Wild 1929). The pathogen also attacks root hairs, roots and stolons, invoking tumours similar to those of potato wart, Synchytrium endobioticum (Karling 1968). Diseased tubers with distorted skin are extremely vulnerable to attack by pathogens causing bacterial soft rots, tuber blight and fungal storage diseases (Harrison et al. 1997).

\section{Migration and establishment of $S$. sub- terranea and PMTV into Europe and Finland}

S. subterranea appears to be indigenous to the Andes (Abbot 1931). The disease was first reported in Europe in 1841 in Braunschweig, Germany, where Wallroth (1842) described the symptoms and the causal agent of the disease found in local potato crop. According to Merz (2008), European farmers faced powdery scab problems well before Wallroth's publication. The pathogen was without doubt spread into Europe around the 1830s in shipments of contaminated tubers from South America, and it was well established in continental Europe and the British Isles during the second half of the 1800s (Harrison et al. 1997).

There are no precise reports on the introduction of $S$. subterranea into the Nordic countries or Finland. In Norway in the 1920s the disease was reported to be more frequent than common scab, Streptomyces spp. (Wollenweber 1921). Liro (1917) in his first edition of the first Finnish textbook on plant pathology mentions $S$. subterranea as a relatively common pathogen on potato, but no detailed description on its distribution or importance is given. The disease has thereafter been reported to be common in Finland but unimportant in comparison with common scab (Jamalainen 1956, Seppänen 1977, 1987). A comprehensive survey on the occurrence of powdery scab has never been carried out in Finland, but Seppänen (1977) stated that the pathogen at that time was present only in cool and wet soils with high organic matter content. More recent circumstantial evidence based on current distribution and rapid spread of PMTV after the 1980s (Kurppa 1989a, Latvala-Kilby et al. 2009, Santala et al. 2010) suggests widespread presence of S. subterranea in Finnish potato production.

PMTV was first detected on potato tubers in Scotland and Northern Ireland in 1965 (Calvert and Harrison 1966), but the likely origin of PMTV is the Andean region of South America (Hinostroza and French 1972). In Norway the virus was described in 1969 (Björnstad 1969) and it was probably introduced into the other three Nordic Countries in the late 1970 s or early 1980 s. The occurrence of the virus was verified in 1983 in Sweden (Rýden et al. 1986, 1989). In Denmark the virus was identified in 1986, though mop-top symptoms were found already in 1967 in Danish seed potato exported to Israel (Nielsen and Mølgaard 1997). In Finland PMTV was identified in 1987 from infested soil but typical spraing symptoms were reported from potato tubers several years earlier (Kurppa 1989a).

PMTV rapidly established itself in Finnish potato production. In 1987 over $40 \%$ of the soil samples collected from starch potato fields were 
Vol. 20(2011): 42-61.

infested and the virus was present at least on $20 \%$ of farms producing processing potato (Kurppa 1989a). In a more recent PMTV survey, carried out in 2005-2008, infected tubers were found throughout the potato production regions in Finland as far north as Rovaniemi in Lapland (Fig. 6) (Santala et al. 2010). Finland has one of the five High Grade (HG) seed potato production zones of Europe, a status indicating freedom from dangerous plant pathogens and pests approved by the European Union (Act 356/95). PMTV was not found in this HG zone (Santala et al. 2010).

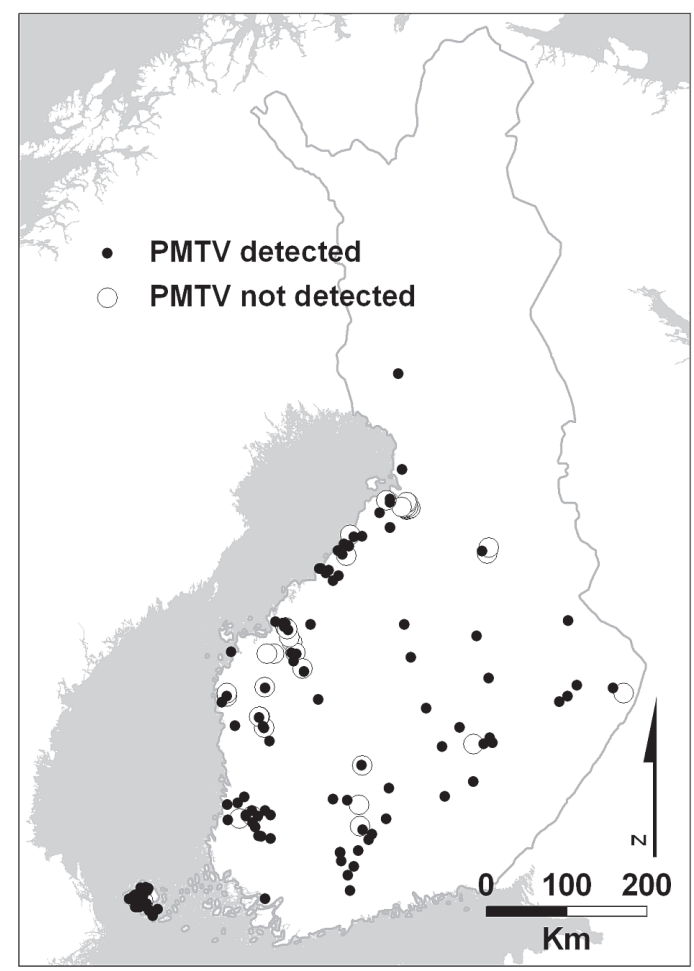

Fig. 6. The incidence of Potato mop-top virus at different potato production districts in Finland in 1987-2007 in tuber and soil samples. The dots do not represent individual samples, but locations where one or more samples have been inspected.

\section{Consequences of powdery scab and PMTV on potato production}

Powdery scab is considered to be of minor importance in Finland (Seppänen 1987). For consumers the scab is largely cosmetic because lesions can be easily removed by manual peeling. Mechanical peeling machines in the potato processing industry are less successful than manual peeling in removing scab lesions and therefore both common and powdery scabs are problematic for the industry. Also seed producers face considerable financial losses when their seed lots are rejected due to tolerance limits for scab incidence (Merz 2008). Certain countries outside the EU important for seed export from Finland have declared $S$. subterranea a quarantine disease. Besides the risk of carrying powdery scab, and especially PMTV, into healthy fields, $S$. subterranean-infected seed can cause considerable yield reductions (Falloon 2008).

The spraing symptom in tubers is especially severe in cool potato production areas. Also the vector, Spongospora subterranea, is adapted to a cool moist climate and it is very common in potato fields in northern Europe (Harrison et al. 1997). In susceptible potato varieties the incidence of spraing in Scandinavia can exceed $30-50 \%$ of the tubers (Nielsen and Mølgaard 1997). In certain varieties like Nicola external symptoms are very clear and symptomatic tubers can be sorted out, but in most cultivars symptoms are internal and they cannot be seen without cutting the tuber in half. In addition, sorting is laborious and only in few cases can infected tuber lots be fed to livestock (Kurppa 1989b).

\section{Management of mop-top and its vector}

The virus is transmitted into new areas in virusinfected seed potatoes (Cooper et al. 1976). It is also obvious that PMTV can spread in resting spores of S. subterranea adhering to potato tubers or resting spores carried by the wind (Santala et al. 2010). The virus can survive in soil for 6-10 years in spores of 
Hannukkala, A. Alien potato pathogens

S. subterranea (Jones and Harrison 1969). There is evidence in the Nordic countries that soil can be PMTV infective after 15 years of storage (Santala et al. 2010).

Management of PMTV and S. subterranea is based on integrated preventive and cultural practices. No effective chemical control is currently available (Falloon 2008). PMTV is not classified as a quarantine pest in the EU and no restrictions on its incidence are set at the EU level (European Union 2000). According to the Finnish Seed Trade Act (728/2000), and the subsequent decrees issued by the Ministry of Agriculture and Forestry, visible spraing symptoms are not allowed in certified seed potato in Finland. There are also limitations in the incidence and severity of total scab symptoms, although no specific limitations for powdery scab have been set. Unfortunately PMTV can also spread in symptomless seed tubers. According to Latvala-Kilby et al. (2009), in certain cultivars over $50 \%$ of tubers can be infected by PMTV though only $2-3 \%$ show visible symptoms. It was also shown in this study that commercial certified seed lots can carry latent PMTV infection.

Long crop rotations, where the period between potato crops is at least five years, are necessary to ensure that populations of both $S$. subterranea and PMTV are reduced. In heavily infested fields serious disease outbreaks have occurred after a 12 year break (Falloon 2008). Currently Finnish seed potato is mainly produced in rotations with a 2-3 year break, and other potato crops largely without any crop rotation (Hannukkala et al. 2007). There are also indications that $S$. subterranea can invoke galls and develop spore balls (resting spores) in roots of non-solanaceous crops, like oat (Avena sativa L.) and yellow mustard (Sinapis alba L.) (Qu and Christ 2006). The possibility of alternative hosts must be considered in planning crop rotations (Falloon 2008).

In fields infested by PMTV, potato cultivars that do not develop abundant symptoms can be grown. The symptom development in tubers is dependent on several poorly understood external factors. Therefore, in some years heavily infested fields can produce almost symptomless tubers while under different weather conditions severe symptom development can take place (Nielsen and Engsbro 1992, Nielsen and Mølgaard 1997, Sandgren et al. 2002). PMTV or powdery scab resistant cultivars would be the durable solution for disease management, but very few, if any, resistance sources are currently available (Santala et al. 2010).

\section{Current status and future perspectives}

PMTV is established in Finnish potato production and it is not possible to eradicate the disease using current quarantine or cultural practices. Numerous new fields are contaminated each year. According to quality analyses carried out by the starch and food potato industry, the proportion of mop-top symptomatic lots has remained relatively stable for the last two decades, representing $1-2 \%$ of processed tuber lots annually (Ossi Paakki, Paula Ilola and Leif Andersson, personal communication). This might indicate that to date farmers have been able to replace severely contaminated fields with healthy ones. It was also shown that a very low proportion of daughter tubers propagated from infected seed tubers become infected, which markedly slows the spread of the disease (Carnegie et al. 2010). In potato intensive regions there is increasing lack of fields suitable for potato production and possibilities for replacing contaminated fields are gradually coming to an end.

In studies of Santala et al. (2010) it was established that part of the certified seed lots can carry symptomless PMTV infection and carry the disease insidiously to new fields. Therefore, appropriate ELISA or PCR-based diagnostic methods should be applied during seed certification to reveal latent infections. The HG seed potato area is still free from mop-top and it is a challenge to keep this region clean. Even certified seed produced elsewhere in Finland should not be used there.

Preventing contamination of new fields in other potato production regions is almost impossible because wind and floods can carry soil from contaminated fields for long distances. Many farmers have recently established different types of companies where several farms use same potato harvester and other 
Vol. 20(2011): 42-61.

expensive machinery. Soil transferred from one farm to another attached to these machines creates a high risk of distributing mop-top and other soilborne diseases from one farm to another.

Ware potato producers have somehow learned to live with the disease. Growing the most susceptible varieties and those showing severe symptom expression is avoided on contaminated fields. This can increase mop-top problems in the long run because cultivars that do not show extreme symptoms can maintain and increase the inoculum level in fields. In addition, also tolerant cultivars can be severely damaged under favourable conditions. PMTV is a serious problem only in the cool climate of Nordic Countries, Scotland and North America and the predicted climate change during decades to come can reduce injuries caused by PMTV in these regions.

In the future maximum efforts should be directed towards breeding potato cultivars that possess true genetic resistance to PMTV and S. subterranea rather than selecting material that does not show extreme symptoms but still carry substantial latent infections (Santala et al. 2010). The problem is that currently only few, if any, sources of resistance are known and research to identify suitable sources of resistance in wild or cultivated potato germplasm should be encouraged, as demonstrated by Sandgren et al. (2002). Recently some very promising potentially resistant sources have been found by the Danish breeding foundation LKF Vandel that might provide future solutions for resistance breeding (Santala et al. 2010).

\section{Conclusions}

The majority of economically important potato diseases have been imported to Finland more than hundred years ago. During the past fifty years only PMTV and Dickeya species are fully new plant pathogens introduced into Finnish potato production. However the biology and the genetic structure of some well established pathogen populations, like $P$. infestans, blackleg and soft rot bacteria and Potato Virus Y (PVY), have changed dramatically.
New aggressive strains of these pathogens have increased direct crop losses and higher economic inputs are needed for their control. Most Finnish potato other than seed is produced without or in very short crop rotations and the production is geographically concentrated in a few regions along the west coast. This enables very rapid spread of any new pest or biologically new pest population throughout potato production. Pests once in adequate control can rapidly come back if appropriate pest management practices are neglected. Global warming can change the relative importance of potato diseases already present in Finland. Warmer climate in future may enhance migration of new diseases like brown ring rot caused by Ralstonia solanacearum, several virus diseases, like Potato Leaf Roll Virus (PLRV) and diseases caused by viroids, like Potato Spindle Tuber Viroid (PSTV). In addition the importance of nematodes and insect vectors of phytoplasmas, viruses and viroids is predicted to increase in warmer climate. Maintaining and developing monitoring systems for existing potato pests and diseases will become increasingly important to maintain biologically and economically sustainable potato production in the future. One important challenge for future potato sector is providing resources and tools for early detection of arousing pest problems and development of adequate cost effective pest management procedures.

Acknowledgements. The author is grateful to the Ministry of Agriculture and Forestry and MTT Agrifood Research Finland for funding the preparation of this review. The author thanks Professor Kari Saikkonen for comments and suggestions to improve the content of the manuscript and to Dr. Jonathan Robinson for careful revising of the English language. Many thanks to Mrs Marjo Segerstedt for technical help during preparation of this manuscript, Mrs Anja Mikkola for providing valuable help in finding historical Finnish publications from the archives of MTT and Miss Eeva Lehtonen from MTT's Gis team for producing the maps in the article. The Author is also grateful to the Finnish Food Safety Authority (EVIRA), especially dr. Mirkka Soukainen and Finnish public and private potato sector for providing unpublished records and statistics on the occurrence of reviewed potato diseases. 
Hannukkala, A. Alien potato pathogens

\section{References}

Abbot, E.V. 1931. Further notes on plant diseases in Peru. Phytopathology 21: 1061-1071.

Adams, M.J., Antoniw, J.F., Kreuze, J. 2009. Virgaviridae: a new family of rod-shaped plant viruses. Archives of Virology 154: 1967-1972.

Alexopoulos, C.J., Mims, C.W. \& Blackwell, M. 1996. Introductory Mycology. $4^{\text {th }}$ edition. John Wiley \& Sons, New York. 869 p.

Baayen, R.P., Cochius, G., Hendriks, H., Meffert, J. P., Bakker, J., van den Boogert, P.H. J. F., Stachewicz, H. \& van Leeuwen G.C. M. 2006. History of potato wart disease in Europe - a proposal for harmonisation in defining pathotypes. European Journal of Plant Pathology 116: 21-31.

Bass, D. \& Cavalier-Smith, T. 2009. Cercozoa. Version 22 March 2009 (under construction). http://tolweb.org/ Cercozoa/121187/2009.03.22 in The Tree of Life Web Project, http://tolweb.org/

Björnstad, A. 1969. Spredning av potet-mopp-topp-virus (PMTV) med settepoteter (Spread of potato mop top virus (PMTV) with seed potato, in Norwegian). Jord og avling $\mathrm{nr}$ 2/1969: 2-4.

Braun, H. 1942. Biologische Spezialisierung bei Synchytrium endobioticum (Schilb.) Perc. (Vorläufige Mitteilung). (in German). Zeitschrift für Pflanzenkrankheiten und Pflanzenschutz 52: 481-486.

CAB International, 1983. Synchytrium endobioticum. Distribution Maps of Plant Diseases, April 1983 (Edition 6) Map 1.

Calvert, E.L. \& Harrison, B.D. 1966. Potato mop-top, a soilborne virus. Plant Pathology 15: 134-139.

Carnegie, S.F., Cameron, A.M. \& McCreath, M. 2010. Foliar symptoms caused by Potato mop-top virus on potato plants during vegetative propagation in Scotland and their association with tuber yield, spraing and tuber infection. Potato Research 53: 83-93.

Colautti, R.I. \& Maclsaac, H.J. 2004. A neutral terminology to define 'invasive' species. Diversity and Distributions 10: 135-141.

Cooper, J.I., Jones, R.A.C. \& Harrison, B.D. 1976. Field and glasshouse experiments on the control of potato mop-top virus. Annals of Applied Biology 83: 215-230.

Curtis, K., M. 1921. The life-history and cytology of Synchytrium endobioticum (Schilb.) Perc., the cause of wart disease in potato. Philosophical Transactions of the Royal Society of London. Series B, Containing Papers of a Biological Character, Volume 210: 409-478.

Czajkowski, R., van Veen, J.A. \& van der Wolf, J.M. 2009. New biovar 3 Dickeya spp. strain (syn. Erwinia chrysanthemi) as a causative agent of blackleg in seed potato in Europe. Phytopathology 99: 27.

De Boer, S.H. 2003. Characterization of pectolytic erwinias as highly sophisticated pathogens of plants. European Journal of Plant Pathology 109: 893-899.

Engsbro, B. 1984. Nogle kartoffelsorters modtagelighed for ringrust (Susceptibility to spraing in some potato varieties, in Danish). Tidsskrift for Planteavl 88: 311-315.

European Union. 2000. Council Directive 2000/29/EC, 8 May, Brussels.
Falloon, R.E. 2008. Control of powdery scab of potato: Towards integrated disease management. American Journal of Potato Research 85: 253-260.

Frank, A.B. 1899. Die Bakterienkrankheiten der Kartoffeln. (in German). Centralblatt für Bakterologie und Pflanzenkrankheiten 5: 98-102, 134-139.

Fry, W.E. 2008. Plant diseases that changed the world. Phytophthora infestans: the plant (and R gene) destroyer. Molecular Plant Pathology 9: 385-402.

Gardan, L., Gouy, C., Christen, R. \& Samson, R. 2003. Elevation of three subspecies of Pectobacterium carotovorum to species level: Pectobacterium strosepticum sp. nov., Pectobacterium betavasculorum sp. nov., and Pectobacterium wasabiae sp. nov. International Journal of Systematic and Evolutionary Microbiology 53: 381-391.

Garrett, K.A., Dendy, S.P., Frank, E.E., Rouse, M.N. \& Travers, S.E. 2006. Climate change effects on plant disease: Genomes to ecosystems. Annual Review of Phytopathology 44: 489-509.

Glynne, M.D. 1926. Wart disease of potatoes: the development of Synchytrium endobioticum (Schilb.) Perc. in "immune" varieties. Annals of Applied Biology 13: 19-36.

Hampson, M.C. 1979. Infection of additional hosts of Synchytrium endobioticum, the causal agent of potato wart disease: 2. Tomato, tobacco and species of Capsicastrum, Datura, Physalis and Schizanthus. Canadian Plant Disease Survey 59: 3-6.

Hampson, M.C. 1981. Potato wart caused by Synchytrium endobioticum: past and future emphases in research. Canadian Journal of Plant Pathology 3: 65-72.

Hampson, M.C. 1993. History, biology and control of potato wart disease in Canada. Canadian Journal of Plant Pathology 15: 223-244.

Hampson, M.C. \& Coombes, J.W. 1985. Stress and stimulus modifications of disease severity in the wart disease of potato. Phytopathology 75: 817-820.

Hannukkala A.O., Kaukoranta T., Lehtinen A. \& Rahkonen, A. 2007. Late-blight epidemics on potato in Finland, 1933-2002; increased and earlier occurrence of epidemics associated with climate change and lack of rotation. Plant Pathology 56: 167-176.

Hannukkala, A., Lehtinen, A., Joutsjoki, T. 2004a. Black leg and soft rot caused by Erwinia-species in Finland. In: E.A.P.R. pathology section meeting, Lille 11-16 July 2004 - France : abstracts. (1 p.).

Hannukkala, A., Pirhonen, M., Laurila, J., Degefu, Y. \& Virtanen, E. 2009. Uusi tyvimätä yleistyy (New blackleg is increasing, in Finnish). Tuottava Peruna 4/2009: 12-14.

Hannukkala, A.O., Rantanen, T., Lehtinen, A., Moisio, K. \& Palohuhta, J-P. 2004b. Tyvi- ja märkämätä siemenperunan alkutuotannossa. (Blackleg and soft rot in first generations of seed potato, in Finnish). In: Hannukkala, A.O. \& Segerstedt, M. (eds.). Perunatyvi- ja märkämädän epidemiologia, diagnostiikka ja hallintakeinot. Maaja elintarviketalous 41. p. 24-31.

Hannukkala, A.O. \& Segerstedt, M. (eds.). 2004. Perunantyvi- ja märkämädän epidemiologia, diagnostiikka ja hallintakeinot (in Finnish). Abstract: Epidemiology, diagnostics and control of blackleg and soft rot on potato. Maa- ja elintarviketalous 41. Jokioinen: MTT Agrifood Research Centre. 57 p.

Harju, P. \& Kankila, J. 1993. Erwinia carotovora contami- 
Vol. 20(2011): 42-61.

nation of Finnish seed potatoes and the prevalence of bacterial subspecies and serogroups. Agricultural Science in Finland 2: 345-352.

Harrison, B.D. \& Jones, R.A.C. 1971. Factors affecting the development of spraing in potato tubers infected with potato mop-top virus. Annals of Applied Biology 68: 281-289.

Harrison, J.G., Searle, R.J. \& Williams, N.A. 1997. Powdery scab disease of potato - a review. Plant Pathology 46: 1-25.

Hey, A. 1957. Zur Rassenanalyse des Kartoffelkrebses Synchytrium endobioticum (SCHILB.) PERC. (in German). Zeitschrift für Pflanzenkrankheiten und Pflanzenschutz 64: 452-457.

Hibbett, D.S., Binder, M., Bischoff, J.F., Blackwell, M., Cannon, P.F., Eriksson, O.E., Huhndorf, S., James, T., Kirk, P.M., Lücking, R., Lumbsch, H.T., Lutzoni, F., Matheny, P.B., McLaughlin, D.J., Powelll, M.J., Redhead, S., Schoch, G.L., Spatafora, J.W., Staplers, J.A., Vilgalys, R., Aime, M.C., Aptroot, A., Bauer, R., Begerow, D., Benny, G.L., Castlebury, L.A., Crous, P.W., Dai, Y-C., Gams, W., Geiser, D.M., Griffith, G.W., Gueidan, C., Hawksworth, D.L., Hestmarks, G., Hosaka, K., Humber, R.A., Hyde, K.D., Ironside, J.E., Kõljalg, U., Kurtzman, C.P., Larsson, K-H., Lichtwardt, R., Longcore, J., Miadlikowska, J., Miller, A., Moncalvo, J-M., MozleyStandredge, S., Oberwinkler, F., Parmasto, E. Reeb, V., Rogers, J.D., Roux, C., Ryvarden, L., Sampaio, J.P., Schüssler, A., Suguyama, J., Thorn, R.G., Tibell, L., Untereiner, W.A., Walker, C., Wang, Z., Weir, A., Weiss, M., White, M.M., Winka, K., Yao, Y-J. \& Zhang, N. 2007. A higher-level phylogenetic classification of the Fungi. Mycological Research 111: 509-547.

Hilli, A.1932. Perunasyövän (Synchytrium endobioticum (Schilb.) Perc.) leviämisen syistä Suomessa ja ulkomailla (in Finnish). Abstract: The reasons of the spread of potato wart (Synchytrium endobioticum (Schilb.) Perc.) in Finland and abroad. Valtion Maatalouskoetoiminnan Julkaisuja N:o 46. Helsinki, Valtioneuvoston Kirjapaino. 249 p

Hinostroza, A.M. \& French, E.R. 1972. Potato mop-top virus in cork-diseased Peruvian potatoes. American Potato Journal 49: 234-239.

Hintikka, T. J. 1929. Perunasyövän levinneisyydestä eri maissa ja muutamista ilmastollisista seikoista sen saastuttamilla alueilla (in Finnish). Referat: Über die Verbreitung des Kartoffelkrbses in verschiedenen Ländern sowie über einige klimatischen Faktoren der verseuchten Gebiete.(in German). Valtion Maatalouskoetoiminnan Julkaisuja N:o 23. Helsinki, Valtioneuvoston Kirjapaino. $96 \mathrm{p}$.

Jamalainen, E.A. 1930. Perunakolera (Blackleg of potato, in Finnish). Pellervon vihko 33: 1-2.

Jamalainen, E.A. 1956. The Plant Pathology Department of the Agricultural Research Centre. The most important diseases of crop plants in Finland and their control. Reports of Plant Pathology Department of Agricultural Research Centre, Tikkurila Finland 18: 1-15.

Janse, J.D. \& Ruissen, M.A. 1988. Characterization and classification of Erwinia chrysanthemi strains from several hosts in the Netherlands. Phytopathology 78: 800-808.

Jones, R.A.C. \& Harrison, B.D. 1969. The behaviour of potato mop-top virus in soil, and evidence for its trans- mission by Spongospora subterranea. Annals of Applied Biology 63:1-17.

Joutsjoki, T., Lehtinen, A. \& Hannukkala, A.O. 2004. Diagnostics of Erwinias on the seed potato production in Finland. In: E.A.P.R. pathology section meeting, Lille 11-16 July 2004 - France : abstracts. (1 p.).

Joutsjoki, T., Laurila, J., Pirhonen, M., Lehtinen, A., Hannukkala, A. 2005. Diagnostics and incidence of black leg caused by Erwinia bacteria in Finland. In: Ritter, E. \& Carrascal, A. (eds). 16th triennial conference of the EAPR, European Association for Potato Research : abstracts of papers and posters, II : poster presentations, July 17 to 22, 2005, Bilbao, Spain. Bilbao: EAPR. 717-718.

Karling, J. S. 1968. The Plasmodiophorales. $2^{\text {nd }}$ edition. New York, USA: Hafner Publishing Co. 256 p.

Kirk, H.G. 2008. Mop-top virus, relationship to its vector. American Journal of Potato Research 85: 261-265.

Kurppa, A. 1989a. The distribution and incidence of potato mop-top virus in Finland as determined in 1987 and on the variation of disease symptoms in infected potatoes. Annales Agriculturae Fenniae 28. Seria Phytopathologia 107: 285-295.

Kurppa, A. 1989b. Reactions of potato cultivars to primary and secondary infection by potato mop-top virus and strategies for virus detection. EPPO Bulletin 19: 593-598.

Köhler, E. 1931. Der Kartoffelkrebs und sein Erreger Synchytrium endobioticum (SCHILB.) PERC. (in German). Landwirtschaftliche Jahrbücher 74: 729-806.

Langerfelt, E., Stachewicz, H. \& Rintelen, J. 1994. Pathotypes of Synchytrium endobioticum in Germany. EPPO Bulletin 24: 799-804.

Latvala-Kilby, S., Aura, J., Pupola, N., Hannukkala, A., Valkonen, J. 2009. Detection of Potato mop-top virus in potato tubers and sprouts: combinations of RNA2 and RNA3 variants and incidence of symptomless infections. Phytopathology 99: 519-531.

Laurila, J., Ahola, V., Lehtinen, A., Joutsjoki, T., Hannukkala, A., Rahkonen, A., Pirhonen, M. 2008. Characterization of Dickeya strains isolated from potato and river water samples in Finland. European Journal of Plant Pathology 122: 213-225.

Laurila, J., Hannukkala, A.O., Nykyri, J., Pasanen, M., Hélias, V., Garlant, L. \& Pirhonen, M. 2010. Symptoms and yield reduction caused by Dickeya spp. strains isolated from potato and river water in Finland. European Journal of Plant Pathology 126: 249-262. .

Liro, J.I. 1917. Tuhosienet. (Fungal diseases, in Finnish). Kustannusosakeyhtiö Otava, Helsinki. 405 p.

Liro, J.I. 1925. Maatalouskoelaitoksen kasvitautiosasto vv. 1924 - 1925. (Annual report of department of plant diseases in agricultural experimental station, in Finnish). Maatalouden Koetoiminnan Keskusvaliokunnan Vuosikertomus: 1925: 25-31.

Luck, G.W., Daily, G.C. \& Erlich, P.R. 2003. Population diversity and ecosystem services. Trends in Ecology and Evolution 18: 331-336.

Ma, B., Hibbing, M.E., Kim, H.-S., Reedy, R.M., Yedidia, I., Breuer, J., Breuer, J., Glasner, J.D., Perna, N.T., Kelman, A., \& Charkowski, A.O. 2007. Host range and molecular phylogenies of the soft rot enterobacterial genera Pectobacterium and Dickeya. Phytopathology 97: 1150-1163. Martin, M.S. 1929. Additional hosts of Synchytrium en- 


\section{AGRICULTURAL AND FOOD SCIENCE}

Hannukkala, A. Alien potato pathogens

dobioticum (Schilb.) Perc. Annals of Applied Biology 16: 422-429.

Meggs, W.J. 2009. Epidemics of mold poisoning past and present. Toxicology and Industrial Health 25: 571-576.

Merz, U. 2008. Powdery scab of potato - Occurrence, life cycle and epidemiology. American Journal of Potato Research 85: 241-246.

Moore, W.C. 1957. The breakdown of immunity from potato wart disease. Outlook on Agriculture 1: 240-243.

Morse, W.J. 1917. Studies upon the Blackleg Disease of the Potato, with Special Reference to the Relationship of the Causal Organisms. Journal of Agricultural Science 8: 79-126. (http://naldr.nal.usda.gov/NalWeb/ HelpJAR.htm).

Nielsen, S.L. \& Engsbro, B. 1992. Susceptibility of potato cultivars to spraing caused by primary infection of Tobacco rattle virus and Potato mop-top virus. Danish Journal of Plant and Soil Science 96: 507-516.

Nielsen, S.L. \& Mølgaard, J.P. 1997. Incidence, appearance, and development of potato mop-top furovirus-induced spraing in potato cultivars and the influence on yield, distribution in Denmark and detection of the virus in tuber by Elisa. Potato Research 40: 101-110

Olson, K. 1991. Potatisens historia (in Swedish), English summary: The history of potato. In: Veteläinen, M. (ed.), Potatis i Norden, En beskrivning av gamla potatissorten bevarande hos Nordiska Genbanken (Potato in the Nordic countries, Description of old potato cultivars maintained in The Nordic Gene Bank). p. 10-15.

Palacio-Bielsa, A., Cambra, M.A. \& Lopez, M.M. 2006. Characterisation of potato isolates of Dickeya chrysanthemi in Spain by a microtitre system for biovar determination. Annals of Applied Biology 148: 157-164

Percival, J. 1910. Potato wart disease, the life history and cytology of Synchytrium endobioticum (Schilb.) Perc. Zentralblatt für Bakteriologie und Parasitenkrankheiten 25: 440-447.

Pérombelon, M.C.M. 1992. Potato blackleg: Epidemiology, host-pathogen interaction and control. Netherlands Journal of Plant Pathology 98 Supplement 2: 135-146.

Pérombelon, M.C.M. 2002. Potato diseases caused by soft rot erwinias: an overview of pathogenesis. Plant Pathology 51: 1-12.

Pérombelon, M.C.M. \& Kelman, A. 1980. Ecology of the soft rot Erwinias. Annual Review of Phytopathology 18: 361-387.

Persson, P. 1991. Soft rot Erwinia spp. attacking potatoes in Sweden with special reference to $E$. carotovora subsp. atroseptica. Plant Protection Reports Dissertations 20. Swedish University of Agricultural Sciences. 34 p.

Pietarinen, E \& Seppänen, E. 1981. Start of seed potato production in Finland. Annales Agriculturae Fenniae 20: 184-187.

Pimentel, D., Zuniga, R. \& Morrison, D. 2005. Update on the environmental and economic costs associated with alien, invasive species in the United States. Ecological Economics 52: 273-288.

Pohjakallio, O. 1963. Kasvipatologia II. Tarttuvat kasvitaudit. (Plant Pathology II. Infectious plant diseases, in Finnish). Werner Söderström Osakeyhtiö, Porvoo, Helsinki. Finland. 375 p.

Pratt, M.A. 1976. A wet-sieving technique for the detection of resting sporangia of Synchytrium endobioticum in soil. Annals of Applied Biology 82: 21-29.

Puttonen, R. 1968. Diseases of cultivated plants in Finland in 1967. Annales Agriculturae Fenniae 7: 189-193.

Qu, X. \& Christ, B.J. 2006. The host range of Spongospora subterranea f. sp. subterranea in the United States. American Journal of Potato Research 83: 343-347.

Rahkonen, A., Virtanen, E., Pulkkanen, M. \& Forsman, K. 2004. Tyvi- ja märkämädän esiintyminen perunan kenttäkokeissa. (Occurrence of blackleg and soft rot in field trials with table potato, in Finnish). In: Hannukkala, A.O. \& Segerstedt, M. (eds.). Perunatyvi- ja märkämädän epidemiologia, diagnostiikka ja hallintakeinot. Maa-ja elintarviketalous 41. p. 32-38.

Rydén, K., Eriksson, B. \& Insunza, V. 1986. Rostringar hos potatis orsakade av potatismopptoppvirus (PMTV). (Spraing in potato caused by potato mop top virus (PMTV), in Swedish). Växtskyddsnotiser 50: 97-102.

Rydén, K. L., Lövgren, L, \& Sandgren, M. 1989. Investigations on potato mop-top furovirus in Sweden. EPPO Bulletin 19:579-583.

Samson, R., Legendre, J.B., Christen, R., Achouak, W. \& Gardan, L. 2005. Transfer of Pectobacterium chrysanthemi (Brenner et al. 1973) Hauben et al. 1998 and Brenneria paradisiacal to the genus Dickeya gen. nov. as Dickeya chrysanthemi comb. nov. and Dickeya paradisiaca comb. nov. and delineation of four novel species: Dickeya dadantii sp. nov., Dickeya dianthicola sp. nov., Dickeya dieffenbachiae sp. nov. and Dickeya zeae sp. nov. International Journal of Systematic and Evolutionary Microbiology 55: 1415-1427.

Sanders, J.G. 1919. The discovery of European potato wart disease in Pennsylvania. Journal of Economical Entomology 12: 86-89.

Sandgren, M., Plaisted, R.L., Watanabe, K.N., Olsson, S. \& Valkonen, J.P.T. 2002. Evaluation of some North and South American potato breeding lines for resistance to Potato mop-top virus in Sweden. American Journal of Potato Research 79: 205-210.

Santala, J., Samuilova, O., Hannukkala, A., Latvala, S., Kortemaa, H., Beuch, U., Kvarnheden, A., Persson, P., Bundgaard-Topp, K., Ørstad, K., Spetz, C., Nielsen, S.L, Kirk, H.G., Budziszewska, M., Wieczorek, P., Obrępalska-Steplowska, A., Pośpieszny, P., Kryszczuk, A., Sztangret-Wiśniewska, J., Yin, Z., Chrzanowska, M., Zimnoch-Guzowska, E., Jackeviciene, E., Taluntytè, L., Pūpola, N., Mihailova, J., Lielmane, I., Järvekülg, L., Kotkas, K., Rogozina, E., Sozonov, A., Tikhonovich, I., Horn, P., Broer, I., Kuusiene, S., Staniulis, J., Uth, J.G, Adam. G. \& Valkonen, J.P.T. 2010. Detection, distribution and control of Potato mop-top virus, a soilborne virus, in northern Europe. Annals of Applied Biology 157: 163-178.

Schaffnit, E. \& Meyer-Hermann, K. 1930. Beiträge zur Kenntnis der Wechselbeziehungen zwishen Kulturpflanzen, ihren Parasiten und der Umwelt. Über den Eifluss der Bodenreaktion auf die Lebensweise von Pilzparasiten und das Verhalten ihrer Wirtspflanzen. (in German). Phytopathologische Zeitschrift 2: 99-166.

Schrader, G. \& Unger, J.G. 2003. Plant quarantine as a measure against invasive alien species: The framework of the International Plant Protection Convention and the plant health regulations in the European Union. Biological Invasions 5: 357-364. 


\section{AGRICULTURAL AND FOOD SCIENCE}

Vol. 20(2011): 42-61.

Schumann, G.L. 1991. Plant diseases: Their biology and social impact. APS-Press, Minnesota, USA. 397 p.

Scortichini, M. 2005. The population structure of some plant pathogenic bacteria: An ecological and adaptive perspective. Journal of Plant Pathology 87: 5-12.

Seppänen, E. 1987. Bacterial and fungal diseases of potatoes in Finland. Journal of Agricultural Science in Finland 59: 153-159.

Seppänen, E. 1972. On the external quality of table potatoes in Finland and factors influencing it. Annales Agriculturae Fenniae 11: 119-134.

Seppänen, E. 1977. Perunarupi ja sen torjunta (Potato scab and its control, in Finnish). Koetoiminta ja Käytäntö 24. 2. 1977: 1-2.

Schilbedrsky, E. 1896. Ein neuer Schorfparasit der Kartoffelknolle. (in German). Berichten der Deutschen Botanische Geshällchaft 14: 36-37.

Sławiak, M., Łojkowska, E. \& van der Wolf, J. M. 2009. First report of bacterial soft rot on potato caused by Dickeya sp. (syn. Erwinia chrysanthemi) in Poland. Plant Pathology 58: 794.

Stanchewicz, H. 1996. Die Krebsresistenzprüfung von Kartoffelzuchtstämmen -Sorten in der Bundesrepublik Deutschland. (in German). Nachrichtenblatt des Deutschen Pflanzenschutzdienstes 48: 181-186.

Taylor, H.V. 1920. The distribution of wart disease. Journal of Ministry of Agriculture 27: 733-738.

Thiede, H. \& Wierling, F., 1960. Zur Methodik der Krebsresistenzprüfung im Laboratorium. (in German). Nachrichtenblatt den Deutschen Pflanzenschutzdienienstens, Berlin 12: 171-172.

Toth, I.K., Bell, K.S., Holeva, M.C. \& Birch. P.R. 2003. Pathogen profile. Soft rot erwiniae: from genes to genomes. Molecular Plant Pathology 4: 17-30.

Tsror, L. (Lakhim) 2009. Assessment of recent outbreaks of Dickeya sp. (syn. Erwinia chrysanthemi) slow wilt in potato crops in Israel. European Journal of Plant Pathology 123: 311-320.

van der Wolf, J.M., Czajkowski, R., Kristelijn, K.Velvis, H., Boomsma, D. \& van Vaerenbergh, J. 2010. New variants of Dickeya and Pectobacterium cause increasing problems with potato blackleg. In: Potato pests diseases: Old enemies, new threats. Abstracts of papers and posters. $13^{\text {th }}-16^{\text {th }}$ September 2010. Carlow. Ireland p. 19.

Varis, E. \& Pietlä, L. 1991. Perunan viljelyhistoria Suomessa,(in Finnish). English summary: The potato in Finland from the past to the present In: Veteläinen, M. (ed.). Potatis i Norden, En beskrivning av gamla potatissorten bevarande hos Nordiska Genbanken (Potato in the Nordic countries, Description of old potato cultivars maintained in The Nordic Gene Bank). p. 36-45.

Wallroth, F.W. 1842. Der Knollenbrand der Kartoffel. (in German). Linnaea 16: 332. http://www.botanicus.org/ page/106157.

Wild, N. 1929. Untersuchungen über den Pulverschoerf der Kartoffelknollen (Spongospora subterranea (Wallr.) Johnson. (in German). Phytopathologische Zeitschrift 1: 367-452.

Wollenweber, H.W. 1921. Verschleppung von Spongospora - oder Schwammschorf durch Pflanzgut. (in German). Mitteilungen der Biologischen Reichsanstalt für Landund Forstwirtschaft 21: 254-255. http://www.bba.de/ veroeff/mitt/pdfs/mitt21.pdf.

Ylimäki, A. 1955. Perunasyövän levinneisyys ja torjunta Suomessa (in Finnish). (Zusammenfassung: Verbreitung und Bekämpfung von Kartoffelkrebs in Finland. (in German) Maataloustieteellinen Aikakauskirja 27: 199-220.

Zadoks, J.C. 2008. The potato murrain on the European Continent and the Revolutions of 1848. Potato Research 51: 5-45. 